\section{Sodium and chloride in rainwater}

PATERSON and Scorer ${ }^{1}$ have suggested that methods used in rainwater analysis for $\mathrm{Na}^{+}$and $\mathrm{Cl}^{-}$may give incorrect results and the increase in $\mathrm{Na} / \mathrm{Cl}$ ratio reported by Hutton and Leslie ${ }^{2}$ for inland samples collected in Victoria (Australia) relative to coastal samples may be an artefact. These suggestions are not acceptable.

Contamination of rainwater samples by $\mathrm{Na}$ is always possible and must be prevented as far as is practicable. In some Victorian samples $\mathrm{Na}$ was recorded at $0.2 \mu \mathrm{mol}$ per $10^{-4} \mathrm{~m}^{3}$ with the limit of detection being 0.1 and thus $\mathrm{Na}$ contamination should not be significant in samples reported as having $2 \mu \mathrm{mol}$ per $10^{-4} \mathrm{~m}^{3}$ or more. The limit of detection of $\mathrm{Cl}$ was $0.5 \mu \mathrm{mol}$ per $10^{-4} \mathrm{~m}^{3}$ and this limit imposes an artificial restriction on the $\mathrm{Na} / \mathrm{Cl}$ ratio in dilute samples. Seawater with a $\mathrm{Na} / \mathrm{Cl}$ ionic ratio of 0.858 when diluted to a $\mathrm{Cl}$ concentration of $3 \mu \mathrm{mol}$ per $10^{-4} \mathrm{~m}^{3}$ will have a ratio of 1 due to rounding to the nearest whole number and the value of $R_{\mathrm{s}}$ of 1.8 expected by Paterson and Scorer ${ }^{1}$ will not be observed in at least 12 of the Victorian samples in their Fig. 3, it will be 1.5 .

Nevertheless, there is enough evidence in the Victorian data to conclude that terrestrial sources contribute significant $\mathrm{Na}$ particularly at inland stations in summer and autumn. Hutton and Leslie ${ }^{2}$ in their Fig. 3 show seasonal variations at six stations from coast to $320 \mathrm{~km}$ inland and in 14 out of the 17 sets of data the $\mathrm{Na} / \mathrm{Cl}$ ratio in autumn is equal to or greater than the ratio in winter and in 9 out of the 11 sets of data the ratio in spring is equal to or less than the ratio in summer. Furthermore, the data in Table 1 give the following regression for 1955

$$
\mathrm{Na} / \mathrm{Cl}=0.89+0.0022 \times d
$$

$\left(r^{2}=0.529, n=24\right)$ and for 1956

$$
\mathrm{Na} / \mathrm{Cl}=0.86+0.0008 \times d
$$

$\left(r^{2}=0.454, n=8\right) .(d=$ distance $(\mathrm{km})$ from ocean in south-west direction). In both years at zero distance the value of the $\mathrm{Na} / \mathrm{Cl}$ ratio is close to 0.86 , the seawater ratio, and that in 1956 , the wetter year for places usually receiving less than $625 \mathrm{~mm}$ of rain, the ratio changes less with distance.

It may be that the Eskdalemuir and Lerwick data (Fig. 2 in ref. 1) are not in error and the Wraymires site may be influenced by abnormal local factors.

\section{J. T. HutToN}

CSIRO Division of Soils, Glen Osmond, South Australia

\footnotetext{
1 Paterson, M. P. \& Scorer, R. S. Nature 254, 491-495

2 Hutton, J. T. \& Leslie, T. I. Aust. J. Agric. Res. 9 , 492-507 (1958).
}

PAterson REPLIES-Hutton has missed the point of our discussion ${ }^{1}$ of the published data on ionic ratios of sodium and chloride in precipitation. Our analysis of data from a number of studies, most of them connected with the European Air Chemistry Network, found that current theories on segregation of these elements after originating in sea salt aerosol, were based on uncorroborated data. When independent results allowed consistency to be checked, no support was found for any real deviation from the seawater ratio of $\mathrm{Cl} / \mathrm{Na}$ which is 1.80 by weight. If chlorine in some form is driven off the sea salt through chemical or photochemical action, it seems to be brought back again in any cloud droplets which form on the aerosol, as would be expected from the high solubility of the $\mathrm{Cl}_{2}$ or $\mathrm{HCl}$ which are the postulated gaseous forms. The Australian data of Hutton and Leslie ${ }^{2}$ was introduced into the discussion because their finding of a deviation from the sea salt ratio, which may be an important result as it has been found in the rather different environment of the dry and clear Australian atmosphere, also requires corroboration by an independent system of sample collection and analysis. Hutton's continuing failure to come to grips with this consideration is indicated by his final statement, made without supporting argument, that "the Eskdalemuir and Lerwick data (in ref. 1) (may not be) in error and the Wraymires site may be influenced by abnormal local factors."

Hutton's claim (refs 2, 3) that much of the sodium and chloride in inland samples arises from terrestrial sources is supported by a considerable weight of evidence, including the reanalysis of Hutton's Mildura data ${ }^{4}$ by Paterson ${ }^{5}$ which indicates that both elements are collected by that rain gauge at a rate which is effectively independent of the amount of rain during the month. This suggests that much of it has arrived as a dry deposit of aerosol, in quantities substantially greater than those found at a similar distance inland in Europe and North America. The range of atmospheric transport of these particles remains an open question, especially in view of Bigg's observation (personal communication) that extensive sampling from aircraft over wide areas of inland Australia has revealed very low concentrations of particles from any natural source. Perhaps the explanation is to be

Table 1 Habitat value data and indices for the amphibans, lizards and birds of Sri Lanka

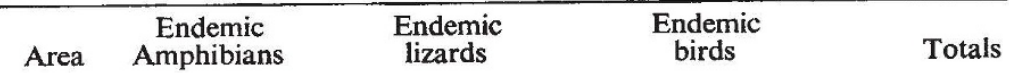

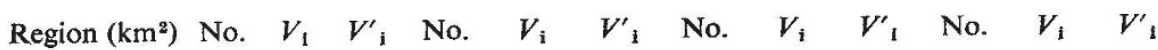
$\begin{array}{llllllllllllll}\text { A } & 43,302 & 0 & 0 & 0 & 5 & 0.12 & 0.12 & 3 & 0.07 & 0.05 & 8 & 0.19 & 0.17\end{array}$ $\begin{array}{llllllllllllll}\text { A } & 43,302 & 0 & 0 & 0 & 5 & 0.12 & 0.12 & 3 & 0.07 & 0.05 & 8 & 0.19 & 0.17 \\ \text { B } & 10,742 & 5 & 0.47 & 0.39 & 7 & 0.65 & 0.65 & 11 & 1.02 & 0.43 & 22 & 2.14 & 1.47\end{array}$ $\begin{array}{llllllllllllll}\text { C } & 7,851 & 7 & 0.89 & 0.71 & 10 & 1.27 & 1.27 & 18 & 2.29 & 1.09 & 35 & 4.45 & 3.07\end{array}$

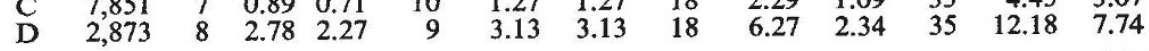

found in Dulhunty's observation ${ }^{6}$ of the intermittent but intense dry storms which raise material from the dry salt lakes in munication) halbally (personal comthe air of 'salt devils' raised by willy willies crossing the dry lake beds.

\section{P. Paterson}

Department of Environment,

Housing \& Community Development, P.O. Box 1890

Canberra City, 2601, Australia

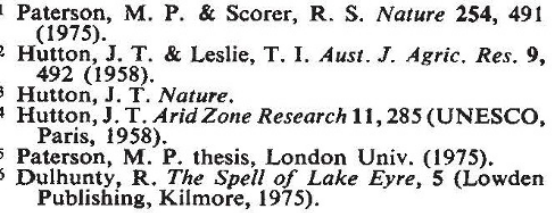

\section{Habitat values and endemicity in the vanishing rain forests of Sri Lanka}

In our paper ${ }^{1}$ the following scientific names were misspelled due to proof reading by committee. The correct spellings are Nannophrys guentheri, ella obscura, Cophotis ceylanica, Lyriocephalus scutatus, Otocryptis wiegmanni, Geckoella triedrus, S. taprobanensis, $S$. diegnani, Nessia burtoni and $A$. hickanala.

Table 2 in the same paper was based on inaccurate estimates of the areas of the Regions. Our figures were obtained Sri Lanka and were too large by a factor of about 1.4. We have prepared a more accurate rendition of the table using the areas in Kahawita ${ }^{2}$ (Table 1), but since the ratios of the areas of the four regions are hardly affected the ratios of the habitat values and our nclusions are conserved.

We thank Dr $H$. Sri Lanka, Peradeniya, Sri Lanka, for pointing out the errors.

\section{F. R. Senanayake}

\section{Department of Entomology,}

University of California,

Davis, California 95616

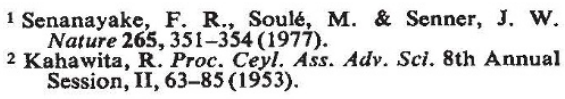

Nature 265, 351-354(1977).

Sci. 8th Annual Session, II, 63-85 (1953). 